\title{
Peer review, politics and pluralism
}

\author{
Chris Harrison* \\ Publishing Division, Cambridge University Press, The Edinburgh Building, Cambridge CB2 2RU, UK
}

\begin{abstract}
The first part of this paper describes the editorial decisions that led to the publishing of The Skeptical Environmentalist (TSE) and the rejection of requests by critics that Cambridge should cease publication on the grounds of claims that it had not been peer-reviewed and that it would be abused by right wing political interests seeking justification for opposing new environmental regulation. The second part focuses on the strengths and weaknesses of peer review and compares the editorial decision-making process, including peer review in journals and book publishers. The third part of the paper explores the role of political considerations in editorial decision-making and compares the controversy surrounding TSE with other recent controversial publications in both the arts and sciences. The final part of the article draws on the work of political scientist and constitutional lawyer Cass Sunstein to argue that the academy is based on the principle of pluralism and that University Presses acting as "general interest intermediaries" have a particular responsibility to publish a wide range of opinion. Political pressure on presses to exercise a form of self-censorship should be resisted.
\end{abstract}

(C) 2004 Elsevier Ltd. All rights reserved.

Keywords: Peer review; Pluralism; Science policy; Environmental policy; Lomborg

\section{Introduction}

Hailed as "a triumph" by The Economist and greeted as "a welcome heretic" by New Scientist but denounced as "a failure" by Scientific American, few books in recent years have provoked such wildly different reactions as Bjorn Lomborg's The Skeptical Environmentalist (TSE). Press reviews on publication were largely positive but were followed by negative notices in Nature, and Science followed by an 11 page attack in the January 2002 issue of Scientific American. ${ }^{1}$ Scientific American's approach was seen by some as excessively one-sided and in turn provoked a flurry of articles in defense of both Lomborg and TSE and critical of what was seen as a politically motivated campaign, which included pressure on its publishers to withdraw the book from publication (see, e.g., Ridley, 2002 and Schoenbrod, 2002). In reviews in the scholarly press, reviewers started increasingly to comment that the reaction to the book was as interesting as the book itself. ${ }^{2}$ TSE became a cause célèbre,

\footnotetext{
* Tel.: +44-1223-325864; fax: +44-1223-315052.

E-mail address: charrison@cambridge.org (C. Harrison).

${ }^{1}$ See http://www.lomborg.com for an extensive set of reviews and links.

${ }^{2}$ See, for example, comments of the reviewer for the European Consortium for Political Research' special interest group on Green politics on the "near-hysterical" reaction of environmentalists (European Consortium for Political Research, 2002). Harvard economist Richard N. Cooper's review of the book observed that the book has provoked "highly critical, even petulant, responses by some scientists in the environmental camp (Cooper, 2002)."
}

and sales, which had always been healthy, started to really take off: sales in the month following the Scientific American articles were four times higher than they had been in the previous month .... A year later, the controversial decision of the Danish Committee on Scientific Dishonesty to uphold complaints of scientific dishonesty against Lomborg returned the book and its author to the headlines, with a similar positive effect on sales. ${ }^{3}$ In December 2003, the Danish Ministry of Science issued a sharp rebuke to the manner in which the Committee on Scientific Dishonesty had investigated the case but, at the time of writing it remains to be seen how this further twist of events will be greeted by supporters, opponents and the book-buying public. ${ }^{4}$

My concern in this article is to explain the editorial decisions that led not just to publishing the book but also to

\footnotetext{
3 Three complaints of scientific dishonesty were lodged with the Danish Academy of Sciences whose ruling was issued in January 2003. The Danish panel issued a ruling finding that in so far as the book could be judged to be a work of "science" rather than a "provocative debate-generating work" Lomborg was guilty of "objective dishonesty" in being selective with his use of data but clearing him of "subjective dishonesty" by which was meant intentionally misleading his readers. This judgment was criticised mildly in Nature (Abbott, 2003), and in more robust terms in editorials in both New Scientist and the Financial Times.

${ }^{4}$ The text of the Danish Ministry of Science ruling is available on http://www.lomborg.com. The Ministry of science decision did not get the same amount of publicity as the DCSD dishonesty ruling but was reported promptly, if sometimes briefly, by Science (Frank, 2004), Nature (Nature Publishing Group, 2004), The Economist, Financial Times and the New York Times.
} 
Cambridge's resistance to concerted pressure to withdraw it from the market. I do so by exploring the strengths and weaknesses of the peer review system and examining some of the political factors at play. It is not the point of this paper to engage in the broader debate about the merits of individual arguments presented within TSE. Comparisons are drawn with other recent controversial works in the literature from both the arts and sciences. The article concludes with thoughts on the overriding importance of maintaining a commitment to pluralism if debate is to flourish and the academy fulfill its proper role in the wider world.

\section{A brief history of The Skeptical Environmentalist}

Many of the critical reviews of TSE went beyond the usual unpicking of a thesis and concentrated instead on the role of the publisher in publishing the book at all. The post tray and email inbox of editors and senior managers at the press bore witness to a concerted campaign to persuade Cambridge to renounce the book. The critics argued that it was likely to be abused by corporate interests and that, in their eyes, it had clearly not been subjected to a proper peer review process.

These complaints were all brought together in a letter to the press in July 2002 signed by twelve distinguished American scientists. Citing the reviews in Nature, Science and Scientific American as evidence, the letter accused the book of being guilty: (1) of containing "numerous factual errors"; (2) of "consistently misrepresenting and misinterpreting data"; (3) of "flawed logic and an alarming misuse of statistics"; and (4) of using selective citations reflecting "an overreliance on secondary, non-peer-reviewed and often anecdotal source material" and of "consistent exclusion of primary literature more closely reflecting the prevailing scientific consensus." The signatories of the letter called on Cambridge to convene a scientific panel to identify every error and misrepresentation in the text and add errata sheets to all copies of the book; to transfer its rights in the book to a popular, non-scholarly publishing house; and, finally, to review our internal procedures to establish how we could have let through a book that is "essentially a political tract".

Cambridge's response to the letter was to acknowledge the controversial nature of the argument in TSE, but to emphasize that, as it had been through the same procedures as any other Cambridge book, it would be quite wrong to abandon an author who had satisfied the requirements of our peer review system. The qualifications (but not of course the names) of the peer reviewers were communicated to the authors of the letter and attention was drawn to the support that, in print, TSE had garnered from well respected natural and social scientists. Finally, an invitation was extended to submit a book proposal offering an opposing argument. To the best of my knowledge there has been no further correspondence. We were, however, surprised and disappointed to see the critics' letter being quoted in an issue of Time magazine (2nd September 2002) coinciding with the Johan- nesburg Earth Summit in which the authors repeated their charge that the book had not been peer-reviewed despite the assurances to the contrary that they had by then received from the press.

As a University Press, we insist on a peer review process for every book we publish. It has become part of the anti-Lomborg folklore that his book bypassed the usual Cambridge peer review process and was cynically spirited through the system by an ignorant social science editor. ${ }^{5}$ This is a charge that has been repeated in many of the public and private attacks on the press, and it is unfounded. Indeed, The Skeptical Environmentalist would never have been published by Cambridge had it not been for peer review.

I was made aware of Bjorn Lomborg through the agency of a distinguished economics professor. As Publishing Director for social sciences, I have been very keen to develop our list on environmental studies: it is not just a growing market, but it is also where some of the most interesting work is being done across the social sciences. The very quantitative approach of the book also seemed to chime with the growing interest in what Dan Esty calls "data-driven environmentalism" (Esty, 2001, 2002). So, when I heard of Lomborg's work I was interested but also cautious and immediately sought the advice of colleagues in our Science group for suitable referees. Indeed, of the four referees who looked at the English translation of a substantial part of Lomborg's original Danish script, three - all from top-ranking environmental studies departments - were chosen from the list used by my colleagues to advise on our environmental science publishing programme rather than from my usual list of social science referees. One was a climate scientist; one was a specialist in biodiversity and sustainable development and one an economist with an expertise on the economics of climate change who was also an IPCC reviewer. Only one of the four reviewers was from a "pure" economics department.

I expected the referees' comments to be mixed and anticipated that our most likely decision would be to decline the book. However, to my surprise all four recommended publication. All of course made suggestions for improvement and one - the biodiversity specialist - suggested that it would be useful to include a commentary from an opposing viewpoint. But the burden of the reports was clearly that the work was worthy of publication, that it avoided what were seen as some of the exaggerations of Julian Simon and offered a nuanced overview of causes for optimism and pessimism in the environmental debate. Given such reports, I therefore, recommended to the Cambridge Syndics

\footnotetext{
5 See, for example, Richard C. Bell, Worldwatch Institute: "In retrospect, it appears that someone did an "end-run" around Cambridge's usually rigorous procedures. Lomborg's book was not published by the natural sciences division of the press, whose editors would have quickly identified the book's ineptness. Instead, the project was quietly spirited through he social sciences division, reportedly without the natural sciences people even knowing of its existence until late in the game. Why that happened is a story waiting to be uncovered (Bell, 2002)."
} 
that a contract be offered for the book provided that the revised and updated English version was approved by a final reader and that the title was changed from the Danish "True State of the World" to (my suggestion) The Skeptical Environmentalist. The proposal was discussed at length at a full meeting of the Syndics and the contract was duly approved.

In this respect, there was nothing different to the procedure adopted for any other Cambridge book. Indeed, given the four positive peer reviews written by scholars trusted both by our science and our social science publishing groups, the interesting peer review question with regard to TSE is on what grounds critics would suggest that the book should have been turned down? However, from the start it was clear that in other respects the book was different tot other books on our list. The editors of Denmark's three leading newspapers, representing a spectrum of political opinion, had all provided references to the effect that the Danish edition of the book had greatly improved the quality of the environmental debate in Denmark. This impressed me as I believe that Denmark, with its high educational standards, is - to adopt the favourite adverb of one of Denmark's leading breweries - probably the closest the modern world gets to the classical ideal of the civic state.

We knew that the book was controversial and likely to provoke a debate. During the editing Bjorn and I argued a good deal ourselves. Indeed, as an editor what I really liked about the book was the way it forced a reaction from the reader. The $\mathrm{BBC}$ environment editor put it rather nicely ending his critical review, thus: "Do read the book. On each page you will find something that you agree with and something that makes you want to bite the carpet. That is good value for money these days" (Cambridge University Press, 2004a). We certainly did not expect everybody to agree with it but we were absolutely sure that it was a thoughtful and legitimate contribution to public debate. We felt it important that to market the book effectively we needed to get the support of as broad a group as possible. The quotes printed on the cover and inside pages of the book give an indication of the wide range of people to whom we sent the script prior to publication. ${ }^{6}$

For marketing purposes, we classified the book as a "trade" book; that is a book of more general potential market appeal than a monograph, that we would promote more aggressively through the retail trade and the media than we would normally do with the bulk of our academic list. We felt that the book had a very positive progressive message

\footnotetext{
6 The list comprised: Matt Ridley a highly respected science writer, Professor Lewis Wolpert, Department of Biology, University College London; Professor Jack Hirshleifer, Department of Economics, UCLA; Professor Lars Kristoferson, Secretary General of Swedish World Wildlife Fund; Professor Nils Petter Gleditsch International Peace Research Institute, Oslo; Professor Richard Rosecrance, Department of Politics, UCLA; Stein W. Bie, Director-General International Service for National Agricultural Research; Jonas Haralz, former Executive Director of the World Bank for the Nordic Countries.
}

in its acknowledgement of the reality of environmental problems, its emphasis on combating poverty and its call for a fairer world trading system and an increase in the levels of development expenditure. Our publicity therefore targeted the liberal press at least as much, if not more than, the conservative press. Indeed it was the liberal UK Sunday paper The Observer which first picked up on the book and its sister paper The Guardian which ran a week long feature on the book in August 2001 just prior to publication (Browne, 2001 and Guardian, 2001). Coverage in The Economist followed (The Economist Print Edition, 2001), with a special "By Invitation" piece in which Lomborg summarized his arguments. In the same week The New York Times science section (Wade, 2001) published a long and largely sympathetic feature by their senior science editor Nicholas Wade. From a publishing point of view, we were naturally delighted with the amount of coverage, whilst the support of a broad range of publications seemed to bear out our editorial judgment that the book cut across standard ideological divides.

The pre-publication press coverage ensured that the book sold out within days of publication but it also spurred opponents into action. Indeed, we received our first protest about our decision to publish the book before it was actually published. Describing the book as "trash" a senior professor threatened never to undertake any work for the press or to consider writing for us again unless we immediately admitted our mistake in publishing it and withdrew it from the market. In the course of a bookshop event in Oxford, Lomborg himself was memorably "pied" by an activist (who was himself writing a book illustrating the effects of global climate change) (Lynas, 2004). More thoughtful and measured rebuttals of the book were offered by the Union of Concerned Scientists and the World Resources Institute in briefings to environmental journalists (World Resources Institute, 2002 and Union of Concerned Scientists, 2003). However, despite such protests, the first wave of book reviews in the press was almost uniformly positive. ${ }^{7}$

With the book out in the public domain it was of course entirely appropriate that its robust argumentation was met with a robust response and a generally interested and open debate. As publishers, we saw our role now as being simply one of keeping the book in print - something that we struggled to achieve in the first few months as we consistently underestimated demand. However, as soon as was practicable we also revised the website relating to the book to include links to the principal critiques of the book as well as the positive endorsements.

This short summary of the chronology of editorial decision-making and marketing strategy behind The Skeptical Environmentalist has attempted to demonstrate that

\footnotetext{
7 The Cambridge website contains extensive links both to the main critiques of the book and the positive media review coverage along with the critical comments (Cambridge University Press, 2004b).
} 
inside the press, ${ }^{8}$ the book was treated no differently to any other Cambridge "trade" book. What then does this say about the peer review process?

\section{Peer review}

Whether at a scholarly press or a top ranked journal, peer review is a tool to help editors filter out the books and articles worthy of publication from those that are not, and to provide guidance and pointers to authors to help them make their books and articles better. It offers no guarantees of always ensuring the "truth".

In the case of TSE, it would be easy to imagine how four different readers, all as well qualified as the four who read the script for Cambridge, could all have made entirely different recommendations. This could happen equally well by chance or by design. Peer review can be used by an editor to assist her reach a decision which in practice she had already taken.

It might be, as has recently been alleged in the case of the journal Regulatory Toxicology and Pharmacology, ${ }^{10}$ that editors are suspected of allowing commercial considerations influence the peer review process. Such accusations, whether founded or not, remind us that the process of peer review is not in itself a guarantee of objective evaluation.

At Cambridge we seek to guard against manipulation of peer review by choosing referees from a range of countries and perspectives. Referees' reports are scrutinized not just by the editor but by his or her peers and managers in house, and then finally by the editorial board, the Syndicate, a committee consisting of leading academics from the University. As with most peer review systems it is a relatively closed one, not subject to external audit but dependent rather upon trust and reputation.

A more serious criticism of peer review is that it is inherently conservative, more likely to reinforce dominant paradigms than challenge existing modes of thought (Frey, 2003). Consider the tale related in a special review article

\footnotetext{
${ }^{8}$ Of course, the sales, media coverage and debate outside the press have been unique for Cambridge.

${ }^{9}$ The shortcomings of peer review were perhaps most spectacularly exposed by physicist Alan Sokal's spoof "Social Text" which was accepted for publication by a leading cultural studies journal despite being deliberately meaningless. See Sokal's website for extensive list of links, http://www.physics.nyu.edu/faculty/sokar/. An older and less well publicised study of 12 psychology journals involved selecting twelve articles at random, giving them different authors, titles and other minor cosmetic changes and then resubmitting them to the same group of journals. Only three journals spotted the hoax and of the remaining nine articles eight were rejected on the basis of new referee reports. This study reported in a 1982 article was described in Karl Svozil "Censorship and the peer review system" (Svozil, unpublished paper).

${ }^{10}$ Virginia A. Sharpe, director of the Center for Science in the Public Interest's Integrity in Research project alleges that a "pro-industry bias" amongst the editors means that the journal reads like "an industry trade publication [...] masked as a peer-reviewed journal (Guterman, 2002)."
}

in BiosScience (Norgaard, 2002) on the publication of TSE by Professor Norgaard, an ecological economist who is very critical of Lomborg. Norgaard described the frustrations he had experienced in having his work repeatedly rejected by leading economics journals. He explained this by the unwillingness of mainstream economics scholars who made up the editorial boards and peer reviewers of the top journals to accept an intellectual approach, which challenged their paradigm. His was a familiar story of a journal article, which challenged mainstream scholarship being rejected by leading field journals. Professor Norgaaard's experience is not so rare and he has some distinguished company: work that was later to be heralded as path-breaking by Nobel economists Gary Becker and George Akerlof failed to pass peer review; Robert May's article on chaos was rejected by Econometrica on the basis of one review but in a slightly altered form became one of the most cited articles on chaos after being submitted as a Comment to Nature; Chemistry Professor Kerry Mullis' work on polymerase chain reaction (PCR), for which he was later to receive the Nobel Prize, was rejected by both Nature and Science (Shepherd, 1995; Nature Publishing Group, 2003; and Campanario, unpublished working paper). Economics Nobel laureate Kenneth Arrow suggests that in the case of the leading economics journals "the publication selection procedure [...] has become methodologically more conservative, more given to preferring small wrinkles in existing analysis to genuinely new ideas (Arrow, 1995)."

Such a charge is probably less easy to sustain in the case of book publishers. The peer review system and the norms by which we operate at Cambridge would ensure that, had Professor Norgaard been submitting a book proposal to the press he would have met with an open mind, although of course acceptance of such a putative book proposal would have been dependent as ever upon a positive set of reviews. Indeed, at much the same time that TSE was being considered I commissioned a textbook on ecological economics I believe that it is important that we have systems in place which help ensure that we publish a range of viewpoints and that we do not use peer review as a pretext for only ever publishing a narrow range of scholarly opinion.

On the other hand, although there is no empirical evidence to prove it, ${ }^{11}$ it is plausible to argue that peer review is more rigorous overall in journals than in books. Referees are asked to comment on relatively short, discrete, disciplinary pieces of work and, as publication in top-ranking journals plays such an important part role in the career chances of scientists, referee comments are generally offered without any financial inducement as it is accepted this forms part of the professorial professional contract in a way that book reviewing does not. This is not to disparage in any way the

\footnotetext{
${ }^{11}$ Several scholars to whom I sent a draft of this article specifically challenged this point and suggested that the rigour of peer review in books compares well with all but the top-ranked journals.
} 
conscientiousness of book reviewers but rather to state what seems the obvious that, other things being equal, a short article reporting a small incremental advancement in knowledge is easier to evaluate than a book surveying and making connections across a wide range of literature. Such an observation might lead to a discussion about what constitutes "peer review" in the case of wide-ranging inter-disciplinary books: should single discipline experts have veto rights over a work that might contain minor errors in discussions of some areas of specialized knowledge but nonetheless present a cogent synthesis? This seems to me an interesting question and might indeed offer grounds for legitimate criticism of the peer review process of TSE. Critics who strictly adopted such an argument would however have to accept that, applied across the board, it would mean that large numbers of important but flawed texts would not have seen the light of day. One obvious book that would never have passed such a test is Rachel Carson's Silent Spring (see Oreskes, 2004).

Peer review is not the only hurdle a script has to clear in order to get accepted. At a not-for-profit press, such as Cambridge, editors and their managers still have to be convinced that a book will sell in sufficient quantities, not just to cover overheads, but also make a surplus that can be reinvested in future publishing. As the academic market becomes tougher - as it has done in recent years - the market potential of book projects comes under closer scrutiny and it is not sufficient for a book to garner strong endorsements from peer review for it to be accepted. Nonetheless, it remains the caseat Cambridge, no book can be accepted, however high the revenue earning potential might be, which does not clear the first hurdle of peer review, and in a generally risk-averse culture there is absolutely no policy of deliberately courting controversy in the hope of generating sales that will cross subsidise slower-selling monographs.

We should neither deify nor demonise peer review. Despite its well-documented shortcomings, ${ }^{12}$ it is unlikely that the academy is ready to abandon it or has anything better to replace it with. ${ }^{13}$ Perhaps, as several analysts have concluded, we may have, as Winston Churchill famously said of democracy, to settle for peer review as the least bad system on offer (Abate, 2004). ${ }^{14}$ We should in any case be very

\footnotetext{
12 The Journal of American Medical Association (JAMA) devoted a special issue to peer review with an editorial that ran: "once again, in this issue of the Journal we publish studies that fail to show any dramatic effect, let alone improvement, brought about by editorial peer review .... Indeed if the entire peer review system did not exist but were now to be proposed as a new invention, it would be hard to convince editors looking at the evidence to go through the trouble and expense (Katiz, 2002)."

13 It is unlikely, for example, that the idea of using a betting market to evaluate new ideas in science discussed will catch on! (Giles, 2002).

14 A Google search on peer review and Winston Churchill throws up a surprisingly large number of articles making the same Churchill analogy!
}

wary of using criticism of the peer review process as a proxy for engaging with substantive arguments.

\section{Politics}

Setting aside peer review, should publishers and editors consider possible political outcomes in their decisionmaking process? For example, were public health charities right to reprimand the British Medical Journal in May 2003 for publishing research suggesting that passive smoking was less harmful than earlier studies had suggested on the grounds that such research would be misused by tobacco industry lobbyists? ${ }^{15}$ Certainly, many of Lomborg's critics were clearly worried by the political impact of TSE, and one of the most commonly recurring arguments advanced against the book is the charge that it plays to a particular political agenda and can be used and abused by vested corporate and political interests. Indeed the Danish Committee on Scientific Dishonesty thought it relevant to note the appeal of the book in the USA, commenting: "The USA is the society with the highest energy consumption in the world, and there are powerful interests in the USA bound up with increasing energy consumption and with the belief in free market forces (Danish Committee on Scientific Dishonesty, 2004).

Professor Peter Raven, past President of the AAAS and one of Lomborg's strongest critics summarized the political concern:

“... it either can be very expensive to change the bases of whole economies on fossil fuels to avoid global warming, which is something that makes governments extremely nervous and for very understandable reasons or, on the other hand, one can believe those who say that the development of alternative energy modes, hydrogen fuel, nuclear fusion, wind power and so forth will provide the basis of whole new industries and will end up enriching economies and making them better off in the not very distant future. Making the transition though is hugely disruptive, and I think it's against that background that one can understand that, if somebody comes along and says: aside from the moon being made of blue cheese there is really no environmental problem, everything is getting better, and a lot of people have said a lot of things over the years and some of them are not true and probably not true now and blah, blah, blah - they will be warmly

\footnotetext{
15 The BBC News reported (2003) that "The UK anti-smoking charity Action on Smoking and Health condemned the BMJ for publishing a "biased" piece of research. Research manager Amanda Sandford said the authors of the study appeared to be deliberately downplaying the findings to suit the tobacco industry. She said: "Questions will inevitably be asked about the decision to publish research conducted by scientists in the pay of the tobacco industry. This could be very damaging as it will be used by industry lobbyists to argue against laws to ban smoking in public places and workplaces."
} 
received by those who wish to win exemptions from the need to do anything."

“... it's completely ignorant and worse, it keeps companies away from acting sensibly about actions that would affect their own future. It keeps governments away from engaging with the world, thinking about real facts and trying to deal with it intelligently so in that sense it's a very serious blow to our children and grand children and it's something that we ought to avoid (Radio National, 2002)."

Well, setting aside the question of whether or not this is a fair summary of Lomborg's thesis, given Professor Raven's stated political commitments, it is easy to understand his concern. However, it is difficult to see how it could be legitimately admitted into the editorial decision-making process of a University Press. Raven here is asking that we make a value-driven judgment about how a book will be used either to advance or to obstruct a particular policy outcome, in this case a rapid transition from an economy dependent upon fossil fuels to one based on renewables. It is not difficult to imagine the outcry if we asked our referees to comment on whether or not a work would support either the Labour or Conservative, Democrat or Republican position on any given policy issue.

TSE was in any case written at a time when social democratic parties sympathetic to the environmentalist agenda dominated most European governments. Although the book was completed during the first few months of the Bush administration, most of it was written at a time when most commentators in the US and in Europe expected Al Gore to secure a relatively straightforward victory in the 2000 presidential election. It would be interesting to speculate on the book's reception had electoral politics in Europe and North America been different. Certainly in Britain, where there was a rock solid majority of the centre left Labour Party with an environmental policy dominated by the importance attached to ratification of Kyoto, it seems that dissenting - heretical - voices such as Lomborg's were welcomed as a way of ensuring debate in a key policy discussion that had hitherto been in danger of becoming a "motherhood and apple pie" issue. Welcome to a dissenting voice was not just forthcoming from the media but also from sectors within the UK's scientific establishment, which was aware of a sense of the growing mistrust of 'science' following the BSE crises and other food scares and mounting public hostility towards GM crops. As a result, in Britain there is a strong push towards promoting an informed and open public debate on major science and public policy issues.

In the US, the political environment could hardly have been more different: a US president with close links to the fossil fuel lobby and other corporate interests not renowned for their environmentalist sympathies came to power at a time when economic recession was starting to bite and funding for advocacy groups was becoming harder. In this con- text, debate can easily become a zero-sum game and liberal pluralist instincts can be overpowered by a sense of fighting for one's survival. Perhaps this climate, as much as anything else, explains the bitterness with which the book was attacked in some quarters in the US, in contrast to the more relaxed reception in Britain.

Whilst it may not be the responsibility of an editor to second-guess how a publication will be received in political circles, it is clear that politicians and advocacy groups have always maintained a keen interest in what is published and that they have sought to influence editorial decisions.

In the following section, I briefly review the cases of three recent publications, which have raised interesting questions of editorial independence, political interference and appropriate ways of challenging claims made in scholarly publications.

\subsection{A clear case of politically motivated interference and attempt to suppress free speech: the case of Judith Levine's harmful to minors: the perils of protecting children from sex}

Judith Levine's book (2002) was written in sober and unsensational style, but its questioning of the wisdom of the laws relating to the age of consent in the US and its argument that sex advice to adolescents should be based on a positive view of adolescent sexuality, rather than on silence and promotion of fear, offended some advocacy groups. Conservative, family values organizations suggested that Levine's argument amounted to a manifesto for paedophilia. Critics called for the Minnesota legislature to withdraw part of its grant to the university and its press as punishment. Robert Knight, director of Concerned Women for America's Culture and Family Institute was quoted as saying: "The action is so grievous and so irresponsible that I felt they relinquished their right to academic freedom". ${ }^{16}$ University of Minnesota Press quite rightly resisted such pressure but acknowledged the strength of feeling on the issue and developed a website with a comprehensive set of links to critics of the book as well as to supportive editorials. In this it was supported by the Free Expression Network, a broad coalition of publishing and free speech interest groups (University of Minnesota Press, 2002).

In this case, the tactics of the conservative critics of the author, book, editor and press probably strike most liberals as being - to put it charitably - heavy-handed. The implications of the case for academic freedom and free speech seem clear-cut and yet in many ways the arguments were very similar to those employed by critics of TSE who called for the book's withdrawal from the Cambridge list. In both cases, the hardest hitting criticisms focused on possible political outcomes and suggestions of abuse of responsible editorial procedure rather than on the substantive argument of the books.

\footnotetext{
16 "University of Minnesota Press book on children's sexuality causes furor; conservatives assail author, publisher" (Star Tribune, 2002).
} 
4.2. A clear case of scholarly malpractice: the case of Bellesille's Arming America

The Emory historian Mr. Bellesiles' study of gun ownership in late 18th and early 19th century America was published in September 2000. In many ways it resembled a typically obscure history monograph focusing on one narrow aspect of society over a relatively small time span and geographic area. Yet its impact on historical and cultural debate proved to be swift and dramatic, as its revisionist thesis, first advanced in the prestigious peer-reviewed Journal of American History, that pre-revolutionary America was not in fact armed to the teeth, was greeted with great enthusiasm by reviewers. The book garnered glowing reviews in both scholarly and more generalist publications such as The New York Review of Books and was awarded the prestigious Bancroft prize for historical excellence by Columbia University. Yet even before the book was published a lot of historians were critical of the methodology on which the JAH article and the book was based. The book was self-consciously targeting contemporary "gun culture" in the US and so it was understandable that many of its supporters initially shrugged off criticisms as partisan and self-interested. Indeed, part of the defense offered by Bellesile's supporters was the allegation that the National Rifle Association was orchestrating the assaults on the book. It seems - perhaps surprisingly! - that such allegations are entirely without foundation. However it became harder to ignore the critiques as more and more historians cast doubt on the authenticity of the archival record on which the book was based. (One set of archives that Bellesiles claimed to have consulted was destroyed in the 1906 San Francisco earthquake.)

As evidence grew of the (quite literally) shaky foundations of Arming America, the peer-reviewed American history journal The William and Mary Quarterly published a special forum debating the book. Introducing the special collection of essays by leading American historians, the journal's editor Robert A Gross wrote:

"Few works of history are free from error, however minor. Yet, even as we insist on accuracy, in citations as well as in factual claims, as the indispensable condition of historical scholarship, it is crucial to go beyond such details and to weigh the larger claims of a work in what 18th century thinkers would call a "liberal" spirit. The contributions that follow, we believe, are faithful to this mandate, as is Michael Bellesiles's response. Arming America is thus a valuable springboard for discussion. However it is judged, it ought to spur further research into an important and little-studied area of American life. And it can attest to the capacity of the historical community to engage in fair-minded, critical discussion of issues, whatever their ideological significance (Gross, 2002).”

Gross's position should not be confused with a position of condoning or being soft on poor data but serves rather as a model of calm stock-taking in a debate which could easily have become highly politicized. Following publication of the Forum, evidence mounted suggesting that the author's research was not simply biased and selective, but was perhaps the result of academic fraud (i.e., introduction of falsified data). Emory University investigated charges of dishonesty and academic fraud, finding the author guilty of these accusations. Bellesiles (2002) resigned from his position at Emory and the Bancroft Prize committee at Columbia University in late 2002 and rescinded their earlier decision. The publishers Alfred Knopf are discontinuing the book, pulping all bookshop returns. A revised second edition is being published by a small independent publisher (HNN Staff, 2004 and Lindgren, 2002).

A lot of the detailed investigation of Bellesiles' data analysis was conducted by James Lindgren, Professor of Law at Northwestern (who happens to have a publicly stated position of support for more gun control and who therefore might have been expected to support Bellesiles' argument). Lindgren believes that the difference between the Bellesiles and Lomborg cases are striking:

"If Michael Bellesiles had done only the things that Bjorn Lomborg is accused of, Bellesiles would never have been investigated at all, because such differences fall within the normal range of scholarly dispute. One must remember that, even with massive evidence suggesting the probable fabrication of data, not one of Bellesiles's academic critics ever filed ethical charges against Bellesiles. Even so, Bellesiles would never have been found guilty of scholarly misconduct if he had responded to critics in the forthright, detailed way that Bjorn Lomborg has. Indeed, the Emory committee's report did not even criticize Bellesiles for having pretended to read 100 wills in Providence, RI, that never existed because Bellesiles had removed the false claim within 9 months of our raising it. The Danish Committee's actions are an assault on academic freedom and an attempt to use government power to enforce scholarly beliefs without being able to persuade scholars in the normal arena of scholarly and public discourse."17

Lindgren's summary of the essential differences between problems of fabricated data and interpretation is forceful and eloquent. Few would disagree with the assertion that there should be no place in the Academy for fabricated data. However, absent any evidence of fabrication, the Academy has a long-standing tradition of entertaining wide ranges of interpretation in the knowledge that willingness to engage in debate with a diversity of viewpoints has long term benefits not just for the musings of the Academy but the well functioning of society. The editors of the peer-reviewed William and Mary Quarterly appear to have understood this truth better than the editor of the - as it happens - un peer-reviewed Scientific American.

\footnotetext{
${ }^{17}$ Personal communication from Professor Lindgren 28th January, 2003.
} 
4.3. Messy politics, messy science and the editorial nightmare: the case of the Chapela and Quist paper in Nature

The dividing line between science and politics is possibly nowhere thinner than in the case of GMO. The high-profile case of Nature's publication of the Quist and Chapela (2001) paper offering evidence of genetic contamination of traditional Mexican maize by GM corn, provides one of the most striking recent examples of the political stakes involved in scientific publishing. ${ }^{18}$ The ferocity of the debate which followed publication of the paper is in itself a cautionary tale. ${ }^{19}$

Part of the debate surrounding the Chapela and Quist paper undoubtedly hinged on science - what were and were not appropriate research techniques and what could and could not be inferred from the result - but the scientific debate was equally unquestionably amplified by the political and economic stakeholders, whether anti-GM activists who trumpeted the results of the original paper on the one hand, or the biotech industry researchers and spokespeople on the other. Each had a clear stake in the outcome of the scientific debate, and the pressure exerted on Nature took on significance much greater than is found in scientific debate alone. It is hard to see how, caught in the middle, Nature could have acted differently, in the end allowing the Chapela and Quist article to stand but prominently displaying the reservations that others within the scientific community had about the validity of the research. The editorial note following the publication of the Kaplinsky et al. (2002) criticism of the Chapela and Quist paper, stated: "In light of these discussions and the diverse advice received, Nature has concluded that the evidence available is not sufficient to justify the publication of the original paper. As the authors nevertheless wish to stand by the available evidence for their conclusions, we feel it best simply to make these circumstances clear, to publish the criticism, the authors' response and new data, and to allow our readers to judge the science for themselves (Nature Publishing Group, 2002)." A decision either to withdraw the paper entirely or to give no space in the journal to its critics would have been a victory for partisan politics and a defeat for scientific enquiry. Most editors would instinctively sympathise with Nature editor Philip Campbell's statement: "Ever since its launch in 1869, Nature has made its own scientific and editorial judgments on the basis of advice from referees (who quite often, as in this case, make differing recommendations.) That is what we did here" (Lepowski, 2002).

In all three cases, issues of science were muddied by the more or less explicit involvement of political actors. Selective strikes by special interest groups against individual publications may be an understandable reaction. Just as a publication can be used to bolster support for a particular political

\footnotetext{
18 The best account of this episode that I have seen is Lepowski (2002).

19 At the time of writing in December 2003, the paper was at the centre of a fiercely contested tenure decision at Berkeley (Dalton, 2003).
}

agenda, so too can demonizing a book serve as a symbolic weapon to advance a larger political agenda. Nonetheless, however much one might sympathize with the political instincts of Lomborg's critics, it is hard to see how these could be legitimately admitted into the editorial decision-making process.

In its insistence on interpretation of claims in the "liberal" spirit of the Enlightenment the William and Mary forum on Arming America is perhaps a lesson to us all. It seems that in the end the historians did a good job of evaluating the merits of the book and were generous enough to acknowledge that even a flawed book (as Arming America appeared to be before the full extent of falsification was known) could still serve as a springboard for useful debate. It is to the key role of open debate and pluralism that we turn in the final section of this paper.

\section{Pluralism}

The decision-making process behind the publication of TSE was thus no different from any other book in Cambridge's academic group and was based solely on the combination of a positive set of peer reviews and a positive assessment of the book's likely market prospects. These twin sets of considerations are widely shared throughout the publishing industry and help to explain why the lists of all major academic publishers contain books reflecting a truly diverse, even contradictory, set of viewpoints. The Cambridge list contains Arne Naess's "deep ecology" text Ecology, Community and Lifestyle: Outline of an Ecosophy and The Skeptical Environmentalist; Princeton University Press, the publisher of Julian Simon's The Ultimate Resource is also the publisher of Hubbert's Peak, documenting the imminent end of oil resources; Blackwell Publishers' list of college texts includes not only some of the market-leading ecology texts but also Julian Simon's edited collection The State of Humanity aimed at the college market; Stuart Pimm's The World According to Stuart Pimm and Ronald Bailey's highly skeptical Earth Report are unlikely bedfellows in McGraw-Hill's catalogue. The only exceptions to this diversity are seen in the niche presses publishing exclusively for distinct communities, often from a committed ideological viewpoint.

For the publishing industry as a whole, this representation of diverse perspectives is something that we celebrate. Most of us are instinctive pluralists, committed to free and open speech and toleration of opposing viewpoints. Whilst dissent from such values has historically been linked to political activism and the perceived effectiveness of a Robespierre or a Lenin in suppressing dissent and driving through a radical political agenda, it is worth noting that there are other forces working against the grain of pluralism, even as media outlets grow more varied and less regulated. University of Chicago law professor Cass Sunstein (2001) warns in Republic.com that the emphasis placed on customization in 
new media may be leading to a situation of increased fragmentation as we have the ability increasingly to choose to listen only to those people whose views we find congenial. He shows how groups who listen only to voices from within the group end up adopting positions that are more extreme than the positions they started off with, and he calls this the 'Echo Chamber' effect. Although his focus is on the Internet, Sunstein's echo chamber also speaks to a pre-digital age. Anybody who participated in activist politics as a student will surely recognize the ideological echo chamber (those who are either too young or apolitical to have experienced it themselves should observe the committee meetings of the Peoples Front of Judea in Monty Python's The Life of Brian for a brilliant lampoon).

How do we prevent the Echo Chamber effect operating? Sunstein argues that the doctrine of the public forum that creates a right of speakers' access, both to places and to people, is central to the defense of free speech. The doctrine originated in safeguarding access to real physical spaces, such as parks, but it can be applied to virtual spaces - such as the Internet - which act as "general interest intermediaries". I would argue that the serious publishing houses in general and the University Presses in particular are important general interest intermediaries. If one could visualize a University Press as a public park, then one would find a park full of professors discoursing and debating on every topic under the sun. A walk in such a park would surely be an enlightening experience (even if proximity to so many loquacious professors might drive us a little crazy!).

Some of the harshest criticisms of TSE seem to be case studies in "cascade effects" and "group polarization", which, Sunstein, argues, are related to the echo chamber. Some of the criticisms - such as the failure to put the book through peer review - have been repeated so frequently that other people take them to be true, and hence repeat them too. Such "cascade effects" amplify and disseminate the distortions that arise from "group polarization". As a result groups of like-minded people who, as individuals, would likely be far more balanced in their opinions, end up subscribing to the most extreme version of the group position on any given topic. ${ }^{20}$ Again the case of TSE affords no shortage of examples of such behavior. It should be said that this observation applies equally well to some of TSE's more gung-ho supporters who have been as guilty of caricaturing the book as some of his more outspoken critics.

Sunstein further suggests that free speech is most effectively defended when it promotes deliberative democracy

\footnotetext{
20 This phenomenon has been widely noted by social scientists. The related concept of "groupthink" was developed in the 1970s by social psychologist Irving Janis. A more recent and topical variant was reported by Paul Krugman in an op-ed in New York Times about US miscalculations in Iraq. Krugman noted that military planners describe a process of "incestuous amplification", defined by Jane's Defense Weekly as "a condition in warfare where one only listens to those who are already in lock-step agreement, reinforcing set beliefs and creating a situation ripe for miscalculation (Krugman, 2003)."
}

(Sunstein, 2001) In this respect, general interest intermediaries, including universities and scholarly presses, have a responsibility to expose their audience to materials, topics and positions that they would not have chosen in advance. As Mary Burgan, general secretary of the American Association of University Professors, wrote in The Chronicle of Higher Education (Burgan, 2002), "the university in a democracy is a place for disputation as well as exploration".

It is difficult to imagine any other field in the early $21 \mathrm{st}$ century where the requirement both for disputation and exploration is so acute as the environment. Our consciousness of the importance of the environment and of the long and complex history of humankind's interaction with the natural world have led to a mushrooming of environmental programmes, not just in the natural sciences but also across the humanities and social sciences. Thus courses in environmental history, once a rarity, are increasingly commonplace; landscape has long been a leitmotif in studies of English literature but it is acquiring a greener tinge (Bate, 2001); political science and economics both have thriving international special interest groups focused on the environment and, within economics, we are witnessing a growth in the emerging school of ecological economics; social psychologists and sociologists are exercised both by environmental influences on our behavior and the development of the myriad new social movements that have sprung up across the western world to help save the planet. And let's not forget the lawyers and the MBAs: courses on environmental law, reflecting the fast growing corpus of national and international environmental legislation and agreements are increasingly commonplace in law schools whilst business schools catering for the increasing demand for courses linking sustainability and business are winning market share in the highly competitive business school market. ${ }^{21}$

In terms of public policy, the environment is one of the dominant issues of our day. The debate over the ratification of the Kyoto Protocol has been conducted fittingly on a truly global scale. The EPA and its counterparts elsewhere in the world dispose of multi-billion dollar budgets (Freeman, 2002 and Sunstein, 2002). Advocates of small states - the Republicans in the US, conservative and Christian Democrat parties in Europe - have a record of voting increases in environment-related expenditure albeit at lower levels than their more environmentally sensitive counterparts in the Democrat, Social Democratic and Green parties. Apart from the amount of dollars involved, environmental policy-making is also notable for the complex interface between expert scientific communities, politicians, advocacy groups, and the public. Given the scale of interest in the environment it is perhaps peculiarly incumbent on the academy and general interest intermediaries to host as full and as open a debate as possible, and one which explicitly acknowledges

\footnotetext{
${ }^{21}$ University of North Carolina's Kenan-Flagler business school is one of the leading schools emphasizing sustainability.
} 
and explains the uncertainties in the science that underpins informed discussion.

The astonishing number of invitations extended to Bjorn Lomborg since publication of the book to debate his arguments reassures me that the academy at large shares the view that the book is a legitimate contribution to an important public debate. The book was launched in London at a public debate hosted by the Royal Institution, as part of its programme of events to encourage the public understanding of science. Lomborg was due to debate the book with the editor of a leading ecology magazine but the opponent pulled out at the last minute. Nonetheless a full house of several hundred scientists, activists and members of the public participated in a lively discussion. Soon afterwards the Natural Environment Research Council, the UK's main funding agency for environmental science, sponsored an on-line debate on the spiked website (Natural Environment Research Council, 2004) on climate change and invited Lomborg to put the case against the Kyoto Protocol. His arguments were countered by a leading climate change scientist, Mike Hulme.

Since then Lomborg has been invited to speak at: the Brookings Institute Center for Regulatory Studies and the American Enterprise Institute (twice); the Lamont Doherty Earth Observatory Columbia University; Harvard University, Yale University Global Institute for Sustainable Forestry and its Globalization Center; Oxford University, Environmental Change Institute; London School of Economics; St. Andrews University; Stockholm University; Rockefeller Foundation; UCLA; Hoover Institution, Stanford University; McGill University; University of Virginia; National Intelligence Council; University of Minnesota; University of Chicago; University of Bonn, Calouste Gulbenkian Foundation in Portugal and Claremont McKenna College. He has been invited to speak at a special round table of OECD Environment experts and participated in a public debate with leading environmental NGO heads on Trade \& Environment hosted by the WTO in Geneva. In the summer of 2002 he was H. Burr Steinbach Scholar at large at Woods Hole, MIT. The New York Times and the British Medical Journal have both commissioned him to write articles and the BBC asked him to write a short television documentary based on the book as part of its programming to coincide with the Johannesburg Earth Summit.

The book is also being used in the classroom. In conjunction with the broader debate, it is for example used as a central case study in a graduate course on "Policy, Science and the Environment" at the University of Colorado where students are invited to compare and evaluate it alongside other texts such as The World According to Stuart Pimm, and Worldwatch Institute reports and asked to explain differences in data and, in some cases, how the same data can lead to such different conclusions.

In short, there is overwhelming interest in the book among the wider public and academic community, and as such it has more than fulfilled the role of a Cambridge "trade" publication. The Cambridge Website for the book, with links to the Danish Committee on Scientific Dishonesty ruling and critical articles in Scientific American and Grist magazine, further encourages the debate. Bjorn Lomborg's own website, with his detailed response to critiques, was praised by New Scientist's review of scientific websites as "without question, ... one of the ten most important environmental sites on the web (New Scientist, 2002)".

I would be delighted, if we could publish a book making an equally powerful and accessible case against the sort of environmental optimism that Lomborg (2001) advances in The Skeptical Environmentalist and take advantage of this platform to advertise this invitation. The public and the academy can surely only be better served by an opportunity to review and debate a wide range of perspectives. In the mean time there is little doubt that the discussion generated by TSE amply fills Cambridge's historic mission "to disseminate knowledge and ideas."

\section{Conclusion}

In the end, the really significant peer review is the open debate that takes place in public once a work has been published. In an editorial defending his decision to publish the controversial study of Bubble Fusion, Science editor Donald Kennedy wrote:

"I have been asked, Why are you going forward with a paper attached to so much controversy? Well, that's what we do; our mission is to put interesting, potentially important science into public view after ensuring its quality as best as we possibly can. After that, efforts at repetition and reinterpretation can take place out in the open. That's where it belongs, not in an alternative universe in which anonymity prevails, rumor leaks out, and facts stay inside. It goes without saying that we cannot publish papers with a guarantee that every result is right. We're not that smart. That is why we are prepared for occasional disappointment when our internal judgments and our processes of external review turn out to be wrong, and a provocative result is not fully confirmed. What we ARE very sure of is that publication is the right option, even - and perhaps especially - when there is some controversy (Kennedy, 2002)."

This seems to me to be as good and succinct a summary of the principles by which scholars and the scholarly press function in an open society as one could hope to find. It is a position which takes as axiomatic that we live in an open pluralist society in which science, politics and public policy are advanced through a willingness to engage in debate with a range of viewpoints, including ones held to be controversial.

Let us return to the question asked at the beginning of this paper of whether it would be appropriate for Cambridge to withdraw the book from its list and summon specially created scientific tribunals to investigate the veracity of every 
single claim made in the book. There is no doubt in my mind that even if resources were available for such an investigation (and the Danish committee acknowledged that this was not a practical option) such a course of action would be the first step on a very slippery slope that could only lead to a more politicized environment for science publishing, in which it would be even harder than it currently is for a range of voices to make themselves heard. This would be a serious blow not just to the market place of ideas but to the diversity of opinion from which in the long run we all benefit.

\section{Acknowledgements}

I am grateful to many people who have taken an interest in this case and who have commented on earlier drafts of this paper: Benito Arruñada, Peter Dougherty, Jeremy Edwards, Bruno Frey, Geoffrey Harcourt, Jack Hirshleifer, James Lindgren, Marshall Meyer, Tim O'Riordan, Mark de Rond, Cass Sunstein, colleagues at Cambridge University Press and from the discussions of fellow panelists and questions from the floor at the AAAS Symposium and a seminar at CIRES University of Colorado, Boulder at which the paper was first presented. I should also like to acknowledge particular thanks to the AAAS symposium convener Roger Pielke Jr. who has helped me more than anybody else to understand the "Lomborg affair" in its wider context. Views expressed in the article are personal and any mistakes are entirely my responsibility.

\section{References}

Abate, T., 2004. What's the verdict on peer review? 21st Century: Ethics in Social Research. Columbia University, http://www.columbia.edu/ $\mathrm{cu} / 21 \mathrm{stC} /$ issue-1.1/peer.htm.

Abbott, A., 2003. Ethics panel attacks environment book. Nature 421, 201. Arrow, K., 1995. Foreword. In: Shepherd, G.B. (Ed.), Rejected: Leading Economists Ponder the Publication Process. Thomas Horton \& Daughters, Arizona.

Bate, J., 2001. Song of the Earth. Harvard University Press, Cambridge, MA.

BBC News, 2003. Row over passive smoking effect: a study suggesting the damaging effect of passive smoking on health may have been overstated has sparked a furious row. BBC News, UK Edition, http://news.bbc.co.uk/1/hi/health/3026933.stm.

Bell, R., 2002. The uninformed environmentalist: how did the skeptical environmentalist pull the wool over the eyes of so many editors? Worldwatch Magazine, March-April.

Bellesiles, M.A. 2002. A.A. Knopf Arming America: The Origins of a National Gun Culture New York.

Browne, A., 2001. Recovering Earth. The Observer, 10th June.

Burgan, M., 2002. Academic freedom in a world of moral crises. The Chronicle of Higher Education, 6 September.

Cambridge University Press, 2004a. The Skeptical Environmentalist: Media \& Reviews. http://uk.cambridge.org/economics/lomborg/ reviews_j.htm.

Cambridge University Press, 2004b. The Skeptical Environmentalist: The Debate. http://uk.cambridge.org/economics/lomborg/websites_j.htm.

Campanario, J.M., unpublished working paper. Rejecting nobel class articles and resisting nobel class discoveries. Rejecting nobel class paper, http://www2.uah.es/jmc/nobel.html.
Cooper, R., 2002. Review of the skeptical environmentalist: measuring the real state of the world. Foreign Affairs, May-June.

Dalton, R., 2003. Berkeley accused of biotech bias as ecologist is denied tenure. Nature 426, 591

Danish Committee on Scientific Dishonesty, 2004. (UVVU), Decision regarding complaints against Bjorn Lomborg? Full text in English available, http://www.forsk.dk/uvvu/nyt/udtaldebat/bl_decision.htm.

Esty, D.C., 2001. Toward data-driven environmentalism: the environmental sustainability index. Environ. Law Rep., xxxi (5), 10603-10612.

Esty, D.C., 2002. Why measurement matters. In: Esty, D.C., Cornelius, P. (Eds.), Environmental Performance Measurement: The Global Report 2001-2002. Oxford University Press, New York.

European Consortium for Political Research, 2002. Book Reviews, The Politics of the Environment: Ideas, Activism, Policy by Neil Carter. Green Polit. Newslett. 1 (2), http://www.essex.ac.uk/ecpr/ standinggroups/green/vollissue2/book_reviews.htm.

Frank, L., 2004. Charges don't stick to The Skeptical Environmentalist. Science 303, 28.

Freeman III, J.M., 2002. Environmental policy since Earth day I: what have we achieved? J. Econ. Perspect. Winter, 125-146.

Frey, B.S., 2003. Publishing as prostitution?: choosing between one's own ideas and academic success. Public Choice 116 (1), 205-223.

Giles, J., 2002. Wanna Bet? Nature 420, 354-355.

Gross, R.A., 2002. Historians and guns. The William and Mary Quarterly, January, http://www.historycooperative.org/journals/wm/59.1/ guns_intro.html.

Guardian, 2001. Crisis. What crisis. Guardian, 15-17 August.

Guterman, L., 2002. Scientists accuse toxicology journal of industry ties. The Chronicle of Higher Education, 6 December.

HNN Staff, 2004. How the Bellesiles Story Developed. Hist. News Network, http://hnn.us/articles/691.html\#latest.

Kaplinsky, N., Braun, D., Lisch, D., Hay, A., Hake, S., Freeling, M., 2002. Maize trangene results in Mexico are artefacts. Nature 416, 601-602.

Katiz, D., 2002. Who reviews the peer review? Mackinac Center for Public Policy, http://www.mackinac.org/print.asp?ID=4568.

Kennedy, D., 2002. To publish or not to publish. Science 295 (8th March).

Krugman, P., 2003. Delusions of Power. New York Times, 28th March.

Lepowski, W., 2002. Biotech's OK Corral. Sci. Policy Perspect., http://www.cspo.org/s\&pp/060902.html.

Levine, J., 2002. Harmful to Minors: The Perils of Protecting Children from Sex. University of Minnesota Press, Minneapolis.

Lindgren, J., 2002. Fall from grace, arming America and the Bellesiles scandal. Yale Law J. 111, 2195-2249, http://www.law.northwestern. edu/faculty/fulltime/Lindgren/Lindgren.html.

Lomborg, B. 2001. The Skeptical Environmentalist. Measuring the Real State of the World. Cambridge University Press, Cambridge.

Lynas, M., 2004. High Tide: News from a Warming World. Flamingo.

Natural Environment Research Council, 2004. Spiked-science debates: The environment spiked science, http://www.spiked-online.com/sections/ science/debates/kyoto/.

Nature Publishing Group, 2002. Editorial note. Nature 416, 601-602.

Nature Publishing Group, 2003. Coping with peer rejection. Nature 425, 645.

Nature Publishing Group, 2004. News in brief: panel ordered to revisit verdict on Lomborg book. Nature 427, 6-7.

New Scientist, 2002. Web Links: Environ. Ecol. 11-20. NewScientist.com, June, http://www.newscientist.com/weblinks/categories/environment2. jsp.

Norgaard, R.B., 2002. Optimists, pessimists and science. BioScience 52 (3), 287-292.

Oreskes, N., 2004. Science and public policy: what's proof got to do with it? Environ. Sci. Policy 7, 369-383.

Quist, D., Chapela, I.H., 2001. Transgenic DNA introgressed into traditional maize landraces in Oaxaca, Mexico. Nature 414, 541-543.

Radio National, 2002. Transcript of the science show on Australian radio national. In: Williams R., Lomborg, B., Raven, P. (Eds.), 2 March, The Science Show, http://www.abc.net.au/rn/science/ss/ stories/s495345.htm. 
Ridley, M., 2002. The profits of doom. The Spectator, 23 February.

Schoenbrod, D., 2002. The mau-mauing of Bjorn Lomborg. Commentary 114 (2), http://www.commentarymagazine.com/Summaries/ V114I2P53-1.htm.

Shepherd, G.B., 1995. Rejected: Leading Economists Ponder the Publication Process. Thomas Horton \& Daughters, Sun Lakes, Arizona.

Star Tribune, 2002. University of Minnesota Press book on children's sexuality causes furor; conservatives assail author, publisher. Associated Press, http://www.startribune.com/stories/389/2202788.html.

Sunstein, C., 2001. Republic.com. Princeton University Press, Princeton, NJ.

Sunstein, C., 2002. Risk and Reason: Safety, Law, and the Environment. Cambridge University Press, Cambridge, UK.

Svozil, K., unpublished paper. Censorship and the peer review system. http://tph.tuwien.ac.at/ svozil/publ/2002-pr.pdf.

The Economist Print Edition, 2001. The truth about the environment. The Economist, 2 August.
Union of Concerned Scientists, 2003. UCS examines The Skeptical Environmentalist by Bjørn Lomborg. Global Environment, http://www. ucsusa.org/global_environment/archive/page.cfm?pageID=533.

University of Minnesota Press, 2002. In: Levine, J. (Ed.), Harmful to Minors: The Perils of Protecting Children from Sex. http://www. upress.umn.edu/Books/L/levine_harmful.html.

Wade, N., 2001. Scientist at Work/Bjorn Lomborg; From an Unlikely Quarter, Eco-Optimism. New York Times, 7 August.

World Resources Institute, 2002. MEDIA KIT: debunking pseudo-scholarship: things a journalist should know about The Skeptical Environmentalist. WRI Report, http://www.wri.org/press/mk_ lomborg.html.

Chris Harrison is Publishing Director for social science publishing at Cambridge University Press. He has a PhD in African History from the School of Oriental and African Studies, University of London. 